\title{
The Pressure on Higher Education Performance and the Process of Lifelong Learning
}

UDK: 378:37.015.311

Alka Obadić

University Zagreb, Faculty of Economics \& Business - Zagreb

aobadic@efzg.hr

Anna-Marija Jakšić

University Zagreb, Faculty of Economics \& Business - Zagreb

\section{ABSTRACT}

Knowledge has become the central resource in the economy of the "information" or "post-industrial" society. Therefore, analysis in the article elaborates European higher education system and the relationship between educational attainment and the employment rate in EU countries and their position in world leading markets. Enclosed, the study analyses the progress and current trends of lifelong learning (LLL) performance in EU and Croatia. The research analyses five EU benchmarks for education and training system set by the European Council, and their implications' on labour market performance. Some synthesis of previous studies is also used. The methodological approach uses the worldwide UN Education Index, the European Commission data on higher education, Eurostat LFS data, and Cedefop data of Vocational Training.

Key words: benchmarks for education and training, higher education, lifelong learning, EU

JEL: $121, J 20, J 23$

\section{Introduction}

In the information society knowledge has become the principle force of production and central resource in the economy over the last few decades. Knowledge can only be effectively accumulated through education. Consequently, the education process and the lifelong learning (LLL) processes are a prerequisite without which it is impossible to succeed 
in the modern post-industrial world. Technical and professional workers play a significant role in modern information societies. It is expected that such trends will increase the pressure on the tertiary levels of education. This leads to the need for more universities and university-based students. For that reason, the analysis in this article involves higher education system and relationship between educational attainment and the employment rate in the world and European leading countries.

As European countries started to lag behind to their main competitors during the last few decades of $20^{\text {th }}$ century, the Lisbon strategy was launched. One of the main Lisbon's' economic concepts was "learning economy" or "knowledge economy", which should be based on improving the European education system and increasing the participation in LLL. The central part of the article analyses the progress towards meeting the five benchmarks set for education and training systems of the EU. Further on, education performance in European countries and their position in world leading markets are analysed. An overall evaluation of the EU performance is compared to the rest of the World by looking at the UN Education Index.

According to some projections, in 2015 around $30 \%$ of all jobs will need high qualifications where almost half will require medium qualifications, including vocational qualifications. That will increase the pressure on tertiary education. Enclosed, the research also elaborates the progress and current trends of LLL performance in EU and Croatia. Increasing participation in lifelong learning for adults remains a main challenge in many European countries.

The article is divided into five main parts. After the introduction, Section 2 provides some theoretical background of "information society" from the nineteenth century to the modern competitive world. Further on, the analysis presents higher education and the labour market performance in European and World leading countries in Section 3. The LLL process of adult population as one of the five benchmarks for education and training is investigated in Section 4. The most important conclusions are presented in the last part of the paper.

\section{Theoretical background}

Speaking about the higher education development, it is important to stress the importance of information and knowledge. When did people 
first begin to perceive that information was so important? In the nineteenth century, John Shaw Billings spoke of geometric progression in the growth of medical literature. And certainly, after World War II, there was much discussion on the "information explosion" or the "exponential growth" of publications. But they did not yet use the terms "information society" and "information revolution" with all of their global implications (Crawford, 1983 , p. 380) were not used yet.

One of the earliest writers to introduce this concept was Fritz Machlup, who published a book in 1962 called The Production and Distribution of Knowledge in the United States ${ }^{\prime}$. Machlup began with a study of the theory of competition and monopoly and ended up with a statistical investigation of knowledge production in the United States. Machlup called the aggregate effort the "knowledge industry" and, by implication, the university that is at the centre of knowledge production and teaching was equated to an industry. Machlup's work led to publications by a series of other authors. In 1969, Peter Drucker, in his best-selling book The Age of Discontinuity", wrote a section on "The Knowledge Society", based upon Machlup's data and projections (Crawford, 1983, p. 381).

The Coming of the Post-Industrial Society, by Daniel Bell, issued in $1973^{3}$, was an immensely popular book. In the postindustrial society, the providing of services made disappear agriculture and manufacturing as a proportion of the GNP. Central to the post-industrial society are the appearance of knowledge, information, and planning as finest activities. A post-industrial society is a society in which an economic conversion has arisen from industrialized based economy to a service based economy. The prerequisites to this economic shift are the processes of industrialization and liberalization. The Bell's theory critique relates to the term "post-industrial". Namely, when historians and sociologists considered the revolution which followed the agricultural society they did not call it "post-agricultural" society/revolution. Instead, they tried to identify the most significant aspect of the new revolution and coined the

1 Machlup, F. (1962). The production and distribution of knowledge in the United States. Princeton, NJ: Princeton University Press. In this study he analyzed the effect of patents on research.

2 Drucker, P. (1968). The age of discontinuity. New York: Harper \& Row.

3 Bell, D. (1976). The Coming of Post-Industrial Society. New York: Basic Books. 


\section{The Pressure on Higher Education Performance and the \\ Process of Lifelong Learning}

term "industrial". Therefore, the term "post-industrial" is problematic, because it implies only a departure, not a direction, and an alternative term should be sought. As a result, the term "information society" is more acceptable.

The prerequisite of successful information society is knowledge that could not be effective in a modern competitive world without the implementation of lifelong learning process. Paul Bélanger (the former Director of the UNESCO Institute for Education) is very familiar with the recent origins of lifelong learning, particularly in the context of education policy, and has made the following observation about the early stages of lifelong learning in the 1970s: „The lifelong education in the early seventies was a euphoria built on the post-war belief in an endless prosperity. But the petrol crisis together with the decline of the welfare state brought rapidly the euphoria to a bottleneck", (Knoll, 2009, p. 104). The process of lifelong learning embraces ithe totality of all formal, non-formal and informal learning throughout a person's entire life cycle«. But, the concept itself must be regarded as inherent to Judaism, and this refers to the area of legend present-day assumptions that lifelong learning is a modern trend (Knoll, 2009, p. 104). Today, we are encouraged, particularly by the EU and the OECD, to regard adult education as an element of lifelong learning, as a process that continuous throughout individual lives and learning biographies.

Machlup, Porat, and Bell argue that we shifted from an agricultural economy to industrial economy during the nineteenth century. After World War II, they continue, we evolved into a service economy. Now, we have become an information economy (Crawford, 1983, p. 382). When economy shifts from industrial economy to a service economy, services make up the largest portion of the GNP4 . The question that can be set up: Has there been a shift from service economy to the information economy? In other words, do information activities now make up a larger portion of the GNP than do services?

The next part of the article, analyses higher education and the labour market performance in European countries and their position in the world

4 Early in the history of the United States, agriculture and mining were the major industries; later, manufacturing surpassed agriculture as a portion of the GNP, and after World War II, services in turn surpassed manufacturing. Looking at employment trends, at the end of fifths in the US, the total number of service workers exceeded the total number of industrial workers (Crawford, 1983, p. 382). 
leading markets and specifies connection between educational attainment and employment rates.

\section{Higher education and labour market performance}

Western industrialised countries are moving on a well-established trajectory of increased knowledge intensity. This is represented by the rise in the proportion of higher education participants and more workers employed in technical and professional occupations (Kaivo-Oja et al., 2002). The results indicate that on the whole the information economy is growing faster than the aggregate economy. Within the information economy, it is the service category that is growing at the highest rate; and among the service industries, the most dynamic industries are the "business services", and "medical, educational, and non-profit organizations" (Apte \& Nath, 2004).

\subsection{Education systems and graduates in higher education}

European countries started to lag behind their main competitors during last few decades of $20^{\text {th }}$ century. Therefore, in 2000 the Lisbon strategy ${ }^{5}$ was launched, the main aim of which was economic, social, and environmental renewal and sustainability - building of "knowledge economy". Since 2000, educational performance has improved considerably in most areas identified by European Education ministers as central for achieving the Lisbon goal. In order to achieve the objectives set for education and training systems of the EU, the Council adopted in May 2003 five benchmarks to be achieved by 2010 and in May 2009, five

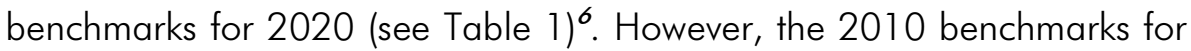
education and training set by Council are not likely to be achieved, apart from the benchmark on increasing the number of mathematics, science and technology graduates (European Commission, 2009, p. 11).

5 Its aim was to make the EU ithe most competitive and dynamic knowledge-based economy in the world capable of sustainable economic growth with more and better jobs and greater social cohesion, "by 2010.

See more detailed: http://europa.eu/scadplus/glossary/lisbon_strategy_en.htm.

6 See Council Conclusions on Reference Levels of European Average Performance in Education and Training (Benchmarks):

http://ec.europa.eu/education/policies/2010/doc/after-council-meeting_en.pdf. 
Table 1: Five EU benchmarks for 2010 and 2020

\begin{tabular}{|c|c|}
\hline 2010 & 2020 \\
\hline $\begin{array}{l}\text { - No more than } 10 \% \text { early school leavers } \\
\text {-Decrease of at least } 20 \% \text { in the } \% \text { of } \\
\text { low-achieving pupils in reading literacy } \\
\text {-At least } 85 \% \text { of young people should } \\
\text { have completed upper secondary } \\
\text { education } \\
\text { - Increase of at least } 15 \% \text { in the number } \\
\text { of tertiary graduates in Mathematics, } \\
\text { Science and Technology (MST), with a } \\
\text { simultaneous decrease in the gender } \\
\text { imbalance } \\
\text { - } 12.5 \% \text { of the adult population should } \\
\text { participate in lifelong learning }\end{array}$ & $\begin{array}{l}\text {-At least } 95 \% \text { of children between } 4 \\
\text { years old and the age of starting } \\
\text { compulsory primary education should } \\
\text { participate in early childhood education } \\
\text { - The share of early leavers from } \\
\text { education and training should be less } \\
\text { tha } 10 \% \\
\text { - The share of low-achieving } 15 \text {-years } \\
\text { olds in reading, mathematics and } \\
\text { science should be less than } 15 \% \\
\text {-The share of } 30-34 \text { years olds with } \\
\text { tertiary educational attainment should } \\
\text { be at leas } 40 \% \\
\text {-An average of at least 15\% of adults } \\
\text { should participate in lifelong learning }\end{array}$ \\
\hline
\end{tabular}

Source: European Commission (2009, p. 14).

Member States are supported in achieving these objectives through the open method of coordination, which uses indicators and benchmarks to inform evidence-based policy making and monitoring progress. Conclusions on progress towards the European benchmarks clearly show that the EU benchmark on mathematics, science and technology (MST) graduates was already reached before 2005. Although there was broad progress of performance, the benchmarks on early school leaving, achievement of upper secondary education and lifelong learning (LLL) are with the current trends not likely to be reached by 2010 (see Figure 1).

Attaining these benchmarks will in many countries demand more effective national initiatives. The figure 1 shows that in the period 2000-2008 performance even deteriorated for reading literacy of young people. Performance and progress on the Adult LLL Participation benchmark shows many countries are catching up and increasing their performance, even though not yet at the 2010 benchmark level $(12.5 \%$ of participation). More about process of LLL will be elaborated in the fourth part of the paper. 
Figure 1: Progress towards meeting the five benchmarks (EU average) for 2010 (2000-2008)

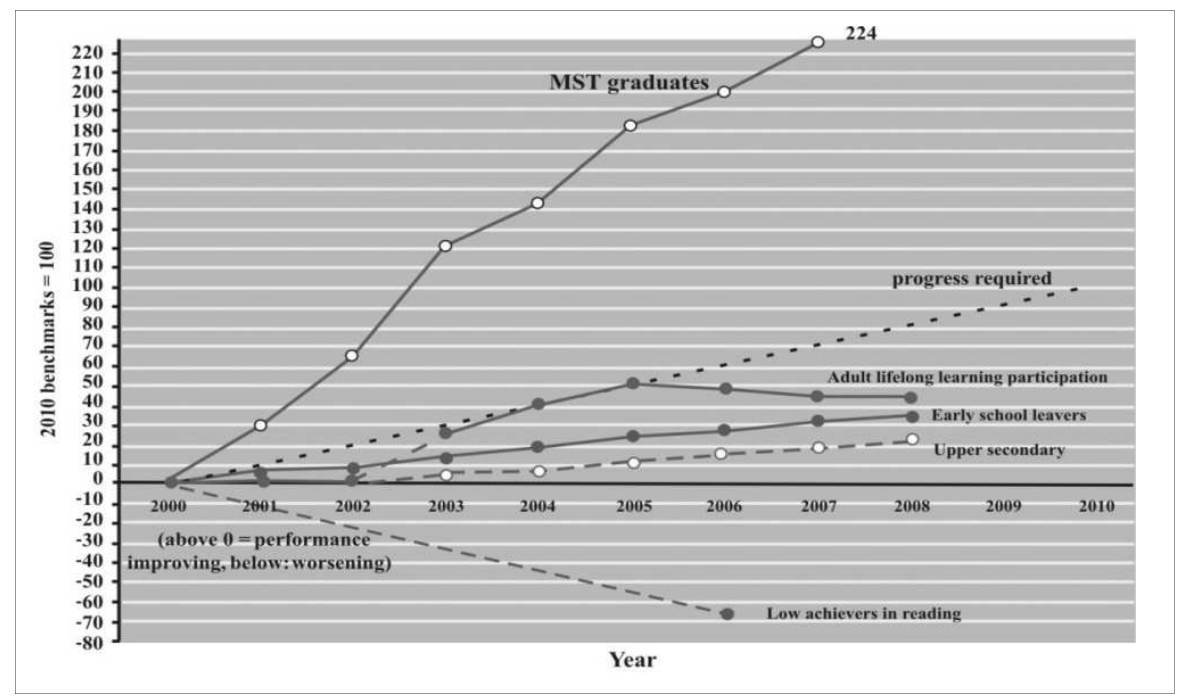

MST - mathematics, science and technology.

In this chart the starting point (in 2000) is set at zero and the 2020 benchmark at 100 .

Source: According to European Commission (2009).

Further on, education performance in European countries and their position in world leading markets are analysed. An overall evaluation of the EU performance compared to the rest of the World can be made by looking at the UN Education Index - one of the three dimensions of the UN Human Development Index (HDI) ${ }^{7}$. Education index gives a statistical picture of a country's relative performances in school enrolment and basic literacy domains. It is constructed based on the adult literacy rate (with two-thirds weighting) and on the gross enrolment rate in the primary, secondary and tertiary levels of education combined (with one-third weighting).

The education index obviously places the EU as a whole among the world's best performers. Australia, New Zealand, Republic of Korea and

7 The HDI - Human Development Index - is a summary composite index that measures a country's average achievements in three basic aspects of human development: health, knowledge, and a decent standard of living. Health is measured by life expectancy at birth; knowledge is measured by a combination of the adult literacy rate and the combined primary, secondary, and tertiary gross enrolment ratio; and standard of living by GDP per capita (PPP US\$). See more detailed at:

http://hdr.undp.org/en/media/HDR_20072008_Tech_Note_1.pdf. 
the US perform slightly better whereas Japan, Brazil, Russian Federation, India and China show lower values of the index (see Figure 2).

Figure 2: Worldwide UN Education Index (in 2007)

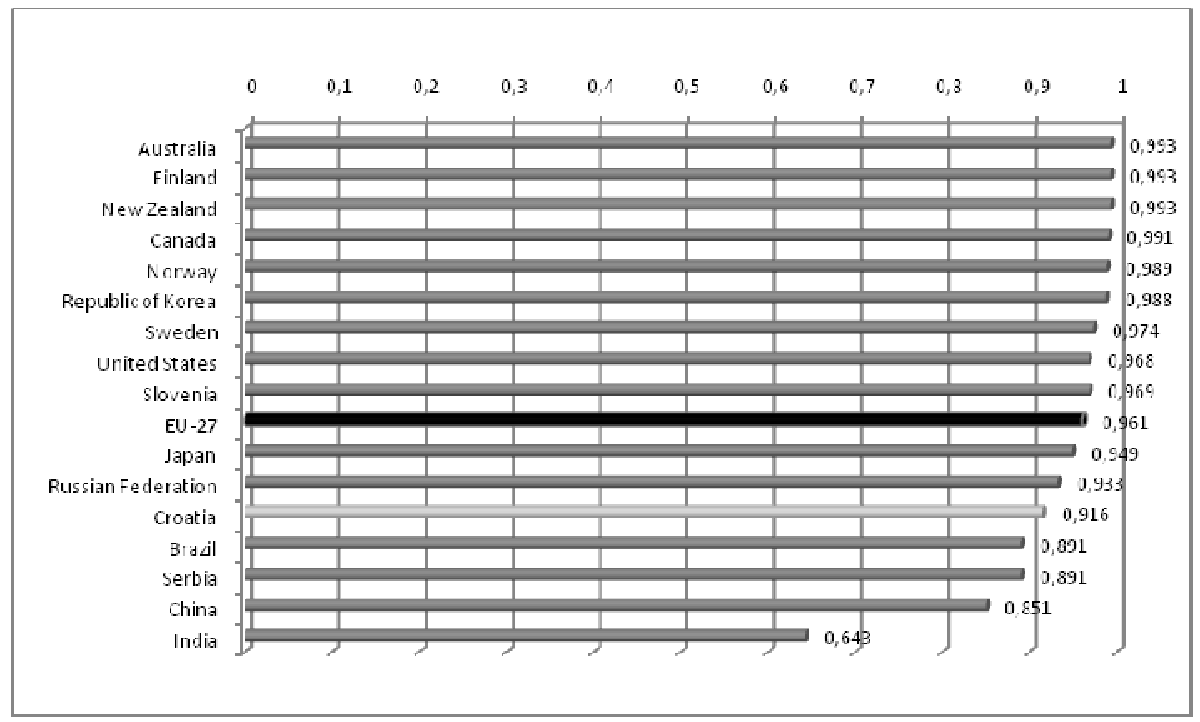

Source: UNDP (2009).

UN Education Index also shows that while the north-eastern EU neighbours are mostly around an equivalent level of the EU average, it's sought eastern and southern neighbours are clearly some way behind.

The emerging knowledge-based information society requires a high supply of highly skilled people. There is a strong demand for tertiary graduates (especially in the field of science and engineering, but also in other fields like languages and economics). As a result, in May 2009 the Council adopted a benchmark on the tertiary attainment of the population: $40 \%$ of 30-34 year olds should by 2020 have tertiary attainment. In 2008, 31\% of 30-34 years old in the EU had tertiary attainment, compared to only $22 \%$ in 2000. In 2008, Cyprus, Denmark, Norway, Finland and Ireland showed the highest tertiary attainment, with rates of over $45 \%$. In general Nordic countries perform well in tertiary attainment of young adults while Southern European countries (with the exception of Spain) and Central European countries with a strong vocational tradition tend to lag behind. The EU countries with the lowest tertiary attainment rates are the Czech Republic, Italy, Romania and Slovakia. The world tertiary graduates have grown by a third since 2000 to reach about 150 million in 2007 . Growth has been particularly strong 
in China, where the number of tertiary students has tripled since 2000. China now has more students than EU or North America. The total number of tertiary graduates has increased in the EU-27 in the period $2000-2007$ by $35 \%$ or $4.3 \%$ per year. Countries that produce a high number of graduates per 1000 young people (> 80) include Denmark, Lithuania and the UK, while at the same time Germany, Italy, Cyprus and Austria produce relatively few each year ( $<40 / 1000$ young people), (European Commission, 2009, p. 61).

Technical and professional workers play a significant role in modern information societies (Kaivo-oja et al., 2002). Science and technology are vital to the knowledge based and increasingly digital economy. Therefore, European Council adopted a benchmark on the total number of graduates in Mathematics, Science and Technology (MST) in the EU which should increase by at least $15 \%$ by 2010 . The number of tertiary MST students has increased by about $16 \%$ since 2000 , or on average by $2.1 \%$ per year. Growth has been particularly strong in Malta, Cyprus and Romania. For some countries, however, the number of MST students stagnated or even declined. The latter was the case in Austria (partly a result of the introduction of tuition fees in 2001/02), Ireland, Belgium, Spain, Bulgaria and Sweden. With a growth of over 33\% in the number of MST graduates in the period 2000-2007, the EU has already progressed with more than twice the rate of the EU benchmark for 2010 in the field (European Commission, 2009, p. 104).

In order to overcome the ICT skills shortage in Europe, seven major ICT companies in Europe (IBM Europe, Nokia Telecommunications, Philips Semiconductors, Thomson CSF, Siemens AG, Microsoft Europe and British Telecommunication Plc.) with the support of the European Commission have formed an "ICT Consortium" and embarked on a pilot project to explore new ways of addressing the skills shortage. The objective of the project is to put in place a framework for students, education and training institutions and governments that describe the skills and competencies required by the ICT industry in Europe ${ }^{8}$.

8 Source: Career Space web site at www.career-space.com/project_desc/serv.htm. 


\subsection{Labour Market Implications - relation between educational attainment and employment rates}

Research over the past decade has produced sufficient evidence that the monetary and non-monetary prosperity of individuals is related to their level of education and training. Education yields substantial returns to the individual in terms of earnings and employability and significant gains in economic growth and wider social benefits. Therefore, there is in general, a positive relationship between educational attainment and employment rate. Yet, employment rates for the population with low level of education are significantly different among EU countries (European Commission, 2009 , p. 65-66). The share of the EU's adult population with high educational attainment is still clearly below key competitors (see Figure 3).

Figure 3: Adult high educational attainment ${ }^{9}$ of 25-64 year olds (in \%), 2008

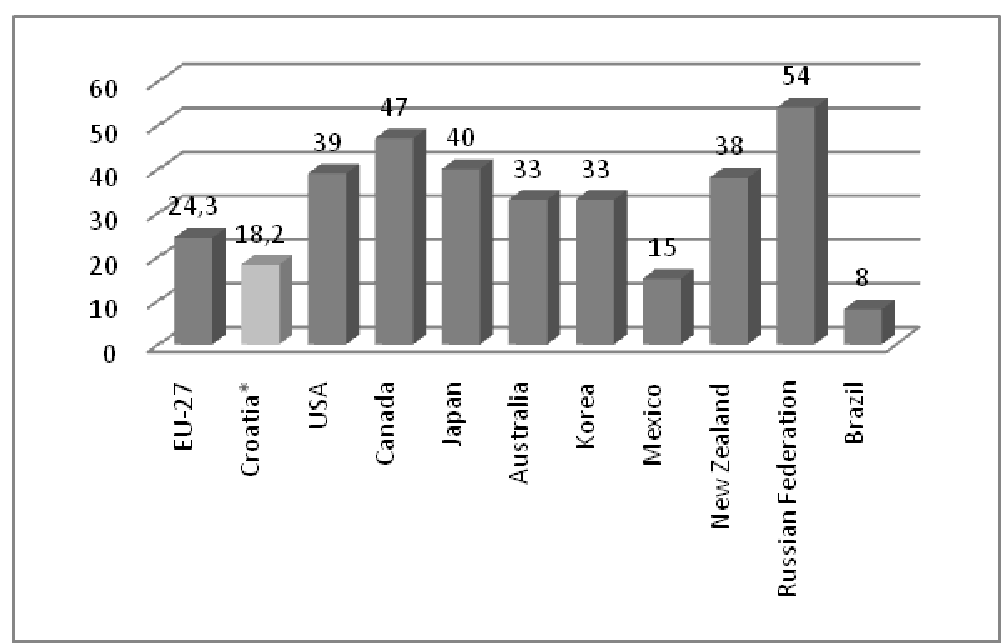

* Data refers to year 2005.

Source: OECD and Eurostat database. LFS data.

The Russian Federation is the best performer at 54\% (though figures might be overstated), Canada second best at 47\%, US and Japan both have a share of around 40\% of 25-64 years old with higher education while Croatia, Mexico and Brazil perform at substantially lower levels than EU-27. The cause of the increase in the share of the population with high educational attainment is that younger generations are better educated than older ones.

9 As a percentage of labour force.

110 Uprava, letnik VIII, 4/2010 
There is also evidence that young people in some countries are seeking to prolong their stay in education as a way of postponing labour market entry. In Britain, applications to attend university increased by $22 \%$ between 2009 and 2010, with increases for those aged 21 to 24 up by $44.8 \%$ and $63.4 \%$ for those aged over 25 (Bell \& Blanchflower, 2010, p. 16).

The first results of the skill needs forecasts at the EU level (undertaken before the unset of the financial and economic crisis) show that the demand for skills and qualifications is being driven upwards in most occupations including in the so-called elementary jobs, by the continuing rise of the service sector and sweeping technological and organisational changes. (Levy \& Murnane, 2005). The forecast, made by European Centre for the Development of Vocational Training, suggests that the total employment increase in Europe between 2006 and 2015 of around 13,5 million new jobs comprises more than 12,5 million additional jobs at the highest qualification level (tertiary education) and almost 9,5 million jobs at the medium level whereas the demand for jobs requiring low qualifications (at most lower secondary education) will fall by 8.5 million. Jobs requiring only low level qualifications will have decreased from around a third in 1996 to around $20 \%$ of the working age population in 2015 (CEDEFOP, 2008).

Figure 4: Past and anticipated employment shares by education attainment level in EU-27

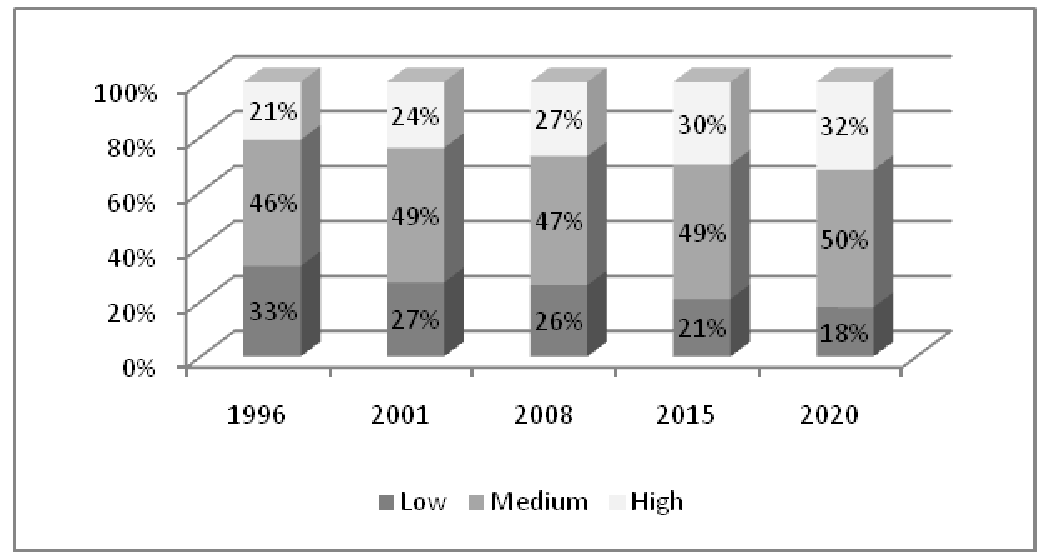

Source: CEDEFOP (2008), http://www.cedefop.europa.eu/default.asp.

Based on the Cedefop projections, in 2015 around 30\% of all jobs will need high qualifications whereas almost half will require medium 
qualifications, including vocational qualifications. It is expected that this will increase the pressure on the upper and postsecondary levels of education (see Figure 4). The challenge will be to improve the quality (and also the access) at these two levels of education (European Commission, 2009, p. 69).

Table 2: Change in employment in selected European countries in Europe classified into educational status 2008 Q1 to 2009 Q3, in \%

\begin{tabular}{|l|r|r|r|}
\hline & $\begin{array}{r}\text { Primary, lower } \\
\text { secondary }\end{array}$ & $\begin{array}{r}\text { Upper secondary } \\
\text { and post-secondary }\end{array}$ & Tertiary \\
\hline EU-27 & -6.3 & -0.98 & 4.71 \\
\hline Czech Republic & -8.95 & -2.63 & 11.17 \\
\hline Estonia & -18.10 & -14.43 & 3.62 \\
\hline Ireland & -24.17 & -12.10 & 2.01 \\
\hline Spain & -14.00 & -5.08 & -0.86 \\
\hline Austria & -6.32 & 2.38 & 10.19 \\
\hline Poland & -1.55 & 0.06 & 14.59 \\
\hline Slovenia & -6.12 & 0.47 & 8.85 \\
\hline Sweden & -1.60 & -1.68 & 2.91 \\
\hline UK & -8.27 & -3.70 & 4.54 \\
\hline Croatia & -0.04 & -1.00 & 6.80 \\
\hline Turkey & 9.34 & 5.07 & 14.52 \\
\hline
\end{tabular}

Source: Eurostat.

There have also been marked changes in employment by educational status. These are shown in table 2, which uses Eurostat data to track how changes in employment have been distributed across International Standard Classification of Education (ISCED). What is evident is that recession has reduced employment more among those with low qualifications than among those with intermediate or higher qualifications. In the EU as whole, employment among those with qualifications up to ISCED Level 2 (lower secondary school) fell by 3.2 million (6.3\%), while for those with tertiary education, employment levels actually increased by $4.7 \%$. The recession appears to have moved Europe towards forms of

112 Uprava, letnik VIII, 4/2010 
production that are more human capital intensive (Bell \& Blanchflower, 2010, p. 17).

The most dramatic falls in low skilled employment have been experienced in countries that experienced house price bubbles, notably including Ireland, the Baltic States and Spain. Employment declined for all levels of education in countries where there were very large falls in output. In general, it could be concluded that there is a general trend to relative worsening of employment prospects for those with low levels of qualifications (Bell \& Blanchflower, 2010, p. 18). The next part of the paper elaborates more about process of lifelong learning.

\section{Process of lifelong learning}

In 2002, the Member States of the European Union committed themselves to develop national lifelong learning strategies (Council Resolution, 2002) covering all contexts (formal, non-formal, informal) and levels (pre-primary, primary, secondary, tertiary, adult) of education and training and all learning activities undertaken through life, with the aim of improving knowledge, skills and competences with a personal, civic, social or employment-related perspective ${ }^{10}$. Following proposals from the Commission, the Council has recommended that monitoring progress in lifelong learning will be covered by indicators on participation of adults in lifelong learning (already available) and on adult skills (which will be available through the new surveys). The benchmark is that $12.5 \%$ of the population aged 25-64 should participate in lifelong learning by 2010 (Badescu, Saisana, 2008, p. 10).

In 2009 close to $10 \%$ of adults in European countries participated in lifelong learning over a four week period. There is clear progress since 2000. However, this is not sufficient to achieve the benchmark of $12.5 \%$ by 2010 - or the 2020 benchmark of $15 \%$. Increasing participation in lifelong learning for adults remains a main challenge in many European countries (European Commission, 2009, p. 33). To a certain extent the slow progress between 2000 and 2005 in the participation of adults in education and training activities is confirmed by the provisional results of the Continuing Vocational Training Survey - CVTS. Participation in continuing vocational training measured by the number of participants

10 Lifelong learning comprises all phases and forms of learning from pre-school to postretirement (European Commission, 2001). 


\section{The Pressure on Higher Education Performance and the \\ Process of Lifelong Learning}

in CVT courses as percentage of employees has decreased in 2005 compared to 1999 in nine countries for which data exists (Belgium, Denmark, Germany, Greece, the Netherlands, Finland, Sweden, United Kingdom and Norway). There are also different patterns of participation among Member States; an increased proportion of employees participate in CVT courses in most of the new Member States which are now catching up in participation with old member states (Badescu \& Saisana, 2008, p. 11).

A new benchmark on lifelong learning has been adopted by the Council (Education) in May 2009: setting the objective of $15 \%$ participation of adults in lifelong learning, by 2020. However, because lifelong learning strategies address the full range of learning from "cradle to grave" - and not just adult education - other European benchmarks, such as participation in preschool education, early leavers from education after compulsory schooling as well as higher education graduation, all support the aim of making lifelong learning a reality (European Commission, 2009, p. 34).

Labour Force Survey shows, that $9.5 \%$ of $25-64$ year olds in 2008 in European countries participate in education and training in the four weeks preceding the survey ${ }^{\prime \prime}$. Even if there has been slow but continuous progress, this is still some way short of the benchmark of 12.5\% for 2010. Only 7 Member States exceeded the benchmark 2020. There are large differences in participation between Member States; the Scandinavian countries and the UK, the best performers, achieve systematically high and increasing participation rates, reaching 20-30\% (see Figure 5).

Data put the Netherlands, Slovenia, Austria, Spain and Ireland in the next group, with participation rates between 10-20\% whereas Estonia, Cyprus, Luxembourg, Germany, Czech Republic and France are at 7-10\% participation rate. Bulgaria, Greece and Romania as well as Croatia and Turkey have recorded little or no progress in improving their extremely low levels of participation. There are different patterns of adult

11 This indicator refers to persons aged 25 to 64 who stated that they received education or training in the four weeks preceding the survey (numerator). The denominator consists of the total population of the same age group, excluding those who did not answer to the question "participation to education and training". Both the numerator and the denominator come from the EU Labour Force Survey. The information collected relates to all education or training whether or not relevant to the respondent's current or possible future job.

114 Uprava, letnik VIII, 4/2010 
participation in lifelong learning by age-group. Participation of adults aged 50-to-64 is considerably lower. Four member states: Denmark, Finland, United Kingdom, and Netherlands along with Iceland and Norway - which are the best performers in Europe for adult participation in lifelong learning overall - are also the best performers but with considerably lower participation rates as concerns this age-group.

Figure 5: Percentage of the adult population aged 25 to 64 participating in education and training (2008)

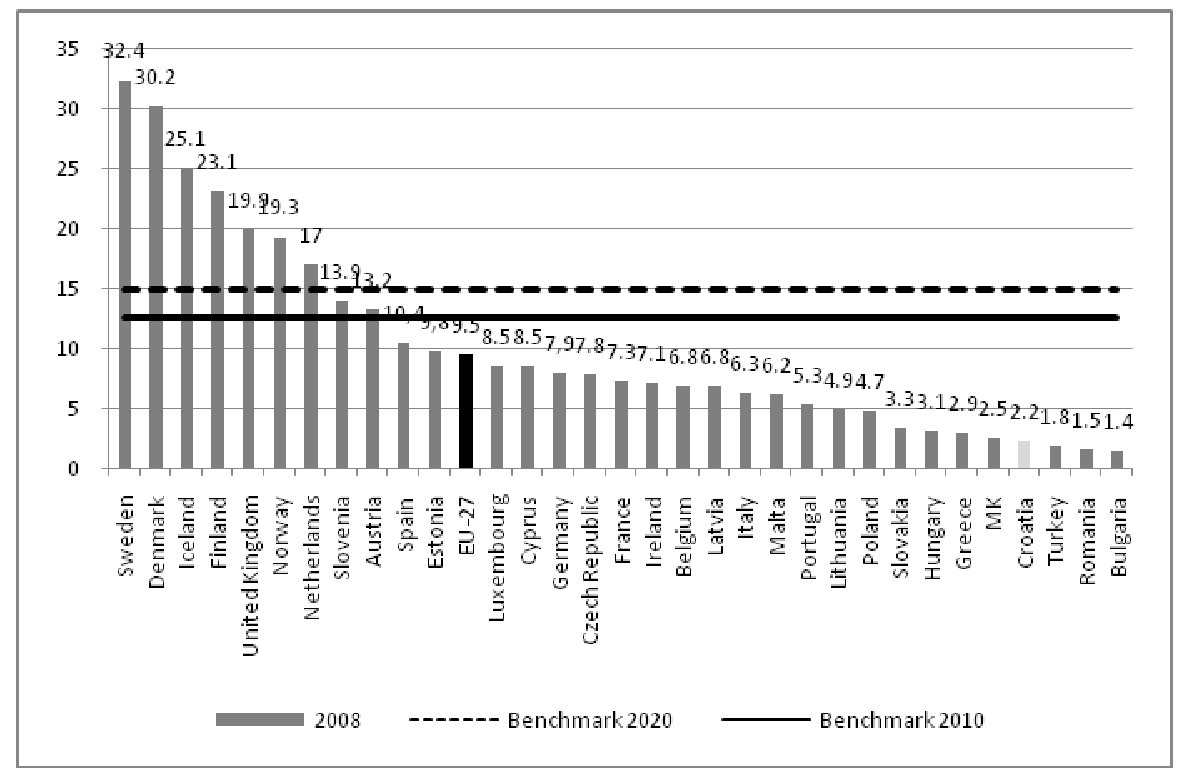

Source: Eurostat (LFS database), October 2009.

All Member States can learn from the best performers in the Union. Therefore, it is important to complete the analysis above by looking at the details in the benchmark areas and in other core indicator areas. This is why the Council asked for the three best performing countries in specific policy areas to be identified (see Table 3).

Half the Member States are best performers in at least one benchmark area. There is therefore a relative big spread of good practice and expertise in the EU among member states (European Commission, 2009, p. 29). The highest percentage of MST graduates per 1000 inhabitants (aged 20-29) in 2007 have France, Finland and Ireland. Second benchmark area - higher education attainment, shows that some countries (Cyprus, Denmark and Finland) already reached a benchmark for 2020. Adult Lifelong learning participation benchmark for 2020 (at 
least 15\%) was already exceeded in 2007 in Sweden, Denmark and Finland. So, it could be concluded that the best performing countries relating to higher education and lifelong learning are Nordic and Scandinavian countries, while South-eastern and Central European countries tend to lag behind.

Table 3: Best performing countries on benchmark relating to higher education and lifelong learning

\begin{tabular}{|c|c|c|c|c|c|c|c|}
\hline & $\begin{array}{l}2010 \\
\text { target for } \\
\text { EU }\end{array}$ & \multicolumn{3}{|c|}{$\begin{array}{l}\text { Best performing countries in the } \\
\text { EU }\end{array}$} & EU & USA & Japan \\
\hline \multirow{6}{*}{$\begin{array}{l}\text { Graduates in } \\
\text { Mathematics } \\
\text { Science } \\
\text { Technology } \\
\text { (per } 1000 \\
\text { young } \\
\text { people) }\end{array}$} & \multirow{6}{*}{$\begin{array}{c}\text { 2010: } \\
\text { Increase of } \\
\text { at least } \\
15 \% \\
\text { graduates }\end{array}$} & \multicolumn{6}{|c|}{ Average annual increase 2000-2007 } \\
\hline & & $\begin{array}{l}\text { Portugal } \\
+14.9 \%\end{array}$ & $\begin{array}{l}\text { Slovakia } \\
+12.6 \%\end{array}$ & $\begin{array}{l}\text { Poland } \\
+12.2 \%\end{array}$ & $+4.2 \%$ & $+2.0 \%$ & $-1.0 \%$ \\
\hline & & \multicolumn{6}{|c|}{ MST Graduates per 1000 inhabitants (aged 20-29) in 2007} \\
\hline & & $\begin{array}{l}\text { France } \\
20.5\end{array}$ & $\begin{array}{l}\text { Finland } \\
18.8\end{array}$ & $\begin{array}{l}\text { Ireland } \\
18.7\end{array}$ & 13.4 & 10.1 & 14.4 \\
\hline & & \multicolumn{6}{|c|}{ \% of female graduates in 2007} \\
\hline & & $\begin{array}{l}\text { Greece } \\
44.2 \%\end{array}$ & $\begin{array}{l}\text { Romania } \\
40.4 \%\end{array}$ & $\begin{array}{l}\text { Bulgaria } \\
39.3 \%\end{array}$ & $31.3 \%$ & $31.0 \%$ & $14.4 \%$ \\
\hline \multirow[b]{2}{*}{$\begin{array}{c}\text { Higher } \\
\text { education } \\
\text { attainment } \\
\text { (age 30-34) }\end{array}$} & \multirow[b]{2}{*}{$\begin{array}{c}\text { 2010: } \\
- \\
\text { 2020: } \\
\text { at least } \\
40 \%\end{array}$} & \multicolumn{6}{|c|}{ Higher education attainment, 2008} \\
\hline & & $\begin{array}{l}\text { Cyprus } \\
47.1 \%\end{array}$ & $\begin{array}{l}\text { Denmark } \\
46.3 \%\end{array}$ & $\begin{array}{c}\text { Finland } \\
45.7 \%\end{array}$ & $\begin{array}{c}31,1 \% \\
\text { Aged } \\
25-34: \\
30.9 \%\end{array}$ & $\begin{array}{c}\text { (2007) } \\
\text { Aged } \\
25-34: \\
40 \%\end{array}$ & $\begin{array}{c}\text { Aged } \\
25-34: \\
54 \%\end{array}$ \\
\hline \multirow[b]{2}{*}{$\begin{array}{c}\text { Adult } \\
\text { Lifelong } \\
\text { Learning } \\
\text { participation } \\
(25-64, \%)\end{array}$} & \multirow{2}{*}{$\begin{array}{c}2010: \\
\text { at least } \\
12.5 \% \\
2020: \\
\text { at least } \\
15 \%\end{array}$} & \multicolumn{6}{|c|}{2008} \\
\hline & & $\begin{array}{c}\text { Sweden } \\
32.4 \% \\
(2007)\end{array}$ & $\begin{array}{l}\text { Denmark } \\
30.2 \%\end{array}$ & $\begin{array}{l}\text { Finland } \\
23.1 \%\end{array}$ & $9.5 \%$ & - & - \\
\hline
\end{tabular}

Source: European Commission (2009, p. 21).

\section{Concluding remarks}

The emerging knowledge-based information society requires a high supply of highly skilled people, so there is a strong demand for tertiary graduates. This is characterized by the rise in the proportion of higher education participants and more workers employed in technical and

116 Uprava, letnik VIII, 4/2010 
professional occupations. Education process and learning process are prerequisite without which it is impossible to succeed in the modern postindustrial world. UN Education index places the EU as a whole among the world's best performance. The world tertiary graduates have grown by a third since 2000 to reach about 150 million in 2007. Growth has been particularly strong in China, where the number of tertiary students has tripled since 2000. China now has more students than EU or North America.

It is evident that recession has reduced employment among those with low qualifications more than among those with intermediate or higher qualifications. Therefore, there is in general, a positive relationship between educational attainment and employment rate. The analysis of five EU benchmarks for education and training systems shows good results in mathematics, science and technology (MST) graduates while for example results in the process of lifelong learning are not satisfactory and not sufficient to achieve the benchmark of $12.5 \%$ by 2010 . Therefore, increasing participation in lifelong learning for adults remains a main challenge in many European countries, although Scandinavian countries and the UK have already reached $20-30 \%$ participants in LLL.

Alka Obadić, Ph.D. is currently working at the Faculty of Economics and Business (University of Zagreb) as an Associate Professor in the Department of Macroeconomics and Economic Development. She was attending EDAMBA Doctoral Programme at Faculty of Economics and Business in Zagreb and Vienna University of Economics and Business between 2000-2003. Her areas of research interest encompass Macroeconomics, Economic Policy, Education Economics and Labour Market. She has actively participated in more than twenty international conferences around the world and published many scientific articles in various domestic and recognized international publications.

Mag. Anna-Marija Jakšić is a Master of Business Studies (Major: Finance). She finished her masters at the Faculty of Economics and Business (University of Zagreb) where she also completed her undergraduate study, specializing in finance. During her study years she acquired knowledge in the fields of public finance, international finance and education economics. 
Alka Obadić, Anna-Marija Jakšić

\section{The Pressure on Higher Education Performance and the}

\section{Process of Lifelong Learning}

\section{References}

- $\quad$ Apte, U.M. \& Nath, H.K. (2004). Size, Structure and Growth of the US Information Economy. Business and Information Technologies, pp. 1-39. Retrieved 7. 7. 2010 from SSRN: http:ssrn.com/abstract=1265825.

- Badescu, M. \& Saisana, M. (2008). Participation in lifelong learning in Europe: What can be measured and compared?; European Commission, JRC (Joint Research Centre) Scientific and Technical Reports, pp. 1-32.

- Bell, D. (1976). The Coming of Post-Industrial Society. New York: Basic Books.

- Bell, N.F.D. \& Blanchflower, D.G. (2010). Recession and Unemployment in the OECD. CESifo, Vol. 11, No. 1, pp. 14-22, Spring 2010.

- $\quad$ CEDEFOP (European Centre for the Development of Vocational Training) (2008). Future skill needs in Europe: medium-term forecast.

- Council Resolution (2002). Lifelong learning. Brussels, 27 June 2002, 2002/C, 163/01.

- Crawford, S. (1983). The Origin and Development of a Concept: The Information Society. Bull. Med. Libr. Assoc. 71 (4): 380-385; October 1983.

- Drucker, P. (1968). The age of discontinuity. New York: Harper \& Row.

- European Commission (2001). Making a European Area of Lifelong Learning a Reality. Communication from the Commission to the Council; COM (2001) 678 final, Brussels, November 2001. Retrieved 2. 7. 2010 from European Commission: http://eurlex.europa.eu/LexUriServ/LexUriServ.do? uri=COM:2001:0678:FIN:EN:PDF

- European Commission (2009). Progress towards the Lisbon Objectives in Education and Training - Indicators and benchmarks. Commission staff working paper.

- Kaivo-oja, J., Ahokas, I., Malaska, P. \& Luukkanen, J. (2002). The information society and changes in the labour market: A comparison of work profile changes in the EU, the USA and Japan. In: Brian Stanford-Smith, Enrica Chiozza and Mireille Edin (Eds.) Challenges and Achievements in Ebusiness and E-Work, pp. 504-511. Amsterdam: IOS Press.

- Knoll, J.H. (2009)."Lifelong learning" - a New Term for an old idea? The Search for Historical Roots. Odgoine znanosti, Vol. 11, No. 1, pp. 103-118. 
Alka Obadić, Anna-Marija Jakšić

The Pressure on Higher Education Performance and the

Process of Lifelong Learning

- Levy, F. \& Murnane, R. J. (2005). The New Division of Labor: How Computerized Work and Globalization Shape Human Skill Demand. Princeton University Press.

- Machlup, F. (1962). The Production and Distribution of Knowledge in the United States. Princeton, NJ: Princeton University Press.

- UNDP (2009). Human Development Report 2009 - Overcoming barriers: Human mobility and development. October 2009. New York, United States.

Uprava, letnik VIII, 4/2010 119 


\section{PRITISKI NA USPEŠNOST VISOKEGA ŠOLSTVA IN PROCES VSEŽIVLJENJSKEGA UČENJA}

$\checkmark$ informacijski družbi je znanje $\vee$ zadnjih nekaj desetletjih postalo osnovni produkcijski tvorec in osrednji vir $v$ gospodarstvu. Znanje se lahko uspešno akumulira samo z izobraževanjem. Torej sta izobraževalni process in vseživljenjsko učenje osnovna pogoja, brez katerih napredek $v$ poindustrijski družbi ni mogoč. Tehnični in strokovni delavci imajo pomembno vlogo $v$ sodobnih informacijskih družbah. Pričakujemo, da bodo ti trendi povečevali pritiske na terciarno izobraževanje. To hkrati pomeni, da bo potrebnih več univerz in več univerzitetno izobraženih študentov. Članek analizira sistem visokega šolstva in odnos med doseganjem izobraževalnih ciljev in stopnjo zaposlenosti $v$ svetu in $v$ vodilnih evropskih državah.

Ker so evropske države v zadnjih desetletjih dvajsetega stoletja pričele zaostajati za svojimi glavnimi tekmeci, so oblikovale Lizbonsko strategijo. Eden glavnih lizbonskih ekonomskih konceptov je bila "učeča se ekonomija" ali "ekonomija znanja", ki naj bi temeljila na izboljšanju evropskega izobraževalnega sistema in naj bi povečala udeležbo $v$ vseživljenskem učenju. Osrednji del članka analizira napredovanje $k$ doseganju petih ciljev meril uspešnosti, ki so bili dogovorjeni za sisteme vzgoje in izobraževanja $v$ državah EU. Nato analizira uspešnost izobraževanja $v$ teh državah in niihov položaj na vodilnih svetovnih trgih. Splošno oceno uspešnosti $\vee$ EU primerja z rezultati preostalega sveta z uporabo Indeksa izobraževanja Organizacije Združenih narodov (United Nations Education Index).

Indeks izobraževanja očitno postavlja EU kot celoto med najbolj uspešne na svetu. Avstralija, Nova Zelandija, Republika Koreja in ZDA so za malenkost boljši, medtem ko Japonska, Brazilija, Ruska federacija, Indija in Kitajska kažejo nižje vrednosti indeksa. Indeks tudi kaže, da so severovzhodne članice EU pretežno blizu ustrezne ravni evropskega povprečja, izbrane vzhodne in južne sosede EU pa očitno malo zaostajajo.

Glede na nekatere napovedi bo leta 2015 približno $30 \%$ vseh poklicev zahtevalo visoko izobrazbo, skorai polovica pa naj bi jih imela srednjo, vključno poklicno izobrazbo. To bo povečalo udeležbo v 
terciarnem izobraževanju. Raziskava, ki je predstavljena $v$ članku, tudi opisuje napredek in sedanje smernice vseživljenjskega učenja $v$ evropskih državah in na Hrvaškem. Povečana udeležba v vseživljenjskem učenju za odrasle ostaja med glavnimi izzivi v mnogih evropskih državah.

Raziskave so v zadnjem desetletju prinesle dovolj dokazov o tem, da je finančno in ne-finančno blagostanje posameznikov povezano z njihovo ravnio izobrazbe in veščin. Izobrazba omogoča znatno donosnost posameznikom glede zaslužka in zaposliivosti ter hkrati povečuje niihovo ekonomsko rast in širše družbene koristi. Na splošno je zato odnos med doseženo izobrazbo in stopjo zaposlenosti pozitiven. Vendar se stopnje zaposlenosti za populacijo z nizko izobrazbo med evropskimi državami značilno razlikujejo. Delež odraslih z visoko izobrazbo v EU je še zmeraj očitno pod njihovimi ključnimi tekmeci. Ruska federacija z 54 \% (čeprav je morda ta števika pretirana) dosega najvišjo stopnjo, Kanada je druga najboljša z $47 \%$, ZDA in Japonska imata obe stopnjo okrog $40 \%$ 25-64 let starih z visoko izobrazbo, medtem ko dosegajo Hrvaška, Mehika in Brazilija znatno nižje stopnje kot EU-27. Povečanje deleža populacije z visoko izobrazbo se kaže zato, ker so mlajše generacije bolje izobražene kot starejše.

Razlike so opazne tudi $v$ zaposlenosti glede na stopnjo izobrazbe. Očitno je, da je recesija zmanjšala zaposlenost bolj med tistimi z nizkimi kvalifikacijasmi kot s tistimi s srednjimi in z visokimi kvalifikacijami. V EU kot celoti je zaposlenost med tistimi s kvalifikacijami do ISCED Level 2 (nižja srednja šola) padla za 3,2 milijone (6,3\%), medtem ko je za tiste s terciarno izobrazbo pravzaprav narastla za 4,7\%. Kaže torej, da je recesija povzročila $\vee$ Evropi premik $k$ proizvodnji, ki zaposluje več človeškega kapitala. Najboli dramatičen padec zaposlenosti pri populaciji z nizko izobrazbo so doživele države, $v$ katerih so bile razne finančne špekulacije, kot npr. Irska, Baltske države in Španija. Zaposlenost se je zmanjšala za vse ravni izobrazbe $v$ državah, kjer se je zelo zmanjšal BDP. $\mathrm{Na}$ splošno lahko sklenemo, da obstaja splošen trend glede sorazmernega poslabšanja možnosti zaposlitve za ljudi z nižjo izobrazbo.

Očitno je, da je recesija zmanjšala zaposlenost med tistimi z nižjo izobrazbo boli kot $\mathrm{s}$ tistimi $\mathrm{s}$ srednjo in visoko izobrazbo. Zato ugotavljamo pozitiven odnos med doseganjem stopnje izobrazbe in stopnjo zaposlenosti. Analiza petih meril EU za sisteme izobraževanja in usposabljanja kaže dobre rezultate za študente, ki so diplomirali 
Alka Obadić, Anna-Marija Jakšić

The Pressure on Higher Education Performance and the

Process of Lifelong Learning

iz matematike, znanosti in tehnologije, medtem ko npr. rezultati za proces vseživljenjskega učenja niso zadovoljivi in ne dosegajo cilja uspešnosti $12,5 \%$ v letu 2010. Zato ostaja za večino evropskih držav glavni izziv povečana udeležba $v$ vseživljenjskem učenju za odrasle, čeprav imajo $v$ skandinavskih državah in $v$ Združenem kraljestvu že zdaj 20-30 \% udeležencev $v$ vseživljenjskem učenju.

122 Uprava, letnik VIII, 4/2010 